\title{
Rozvoj profesního vidění studentů oboru Učitelství pro mateřské školy
}

\author{
Zora SysLOVÁ
}

\begin{abstract}
Abstrakt: Předložená studie prináši do odborného diskurzu pohled na rozvoj profesního vidèni jako jedné z důležitých dimenzi profesionality učitelù mateřských škol. Jejim cílem je popsat povahu profesního vidèni studentü oboru Učitelstvi pro mateřrké školy a zmèn, které nastaly po systematické reflexi videonahrávek reálného vzděláváni v mateřské škole. Respondenty výzkumu se stalo 18 studentek oboru Ucitelstvi pro mateřské školy Pedagogické fakulty Masarykovy univerzity. Data byla sbirána na začátku semestru, ve kterém probihala intenzivni práce s videonahrávkami, a v následujicim semestru. Pisemné komentáre studentek byly analyzovány pomoci dvou kategoriálnich systémů. Prvni zachytil zaměreni jejich pozornosti, druhý zpưsob uvažováni o vidèném. Rozdilnosti v zaměreni pozornosti a zastoupeni myšlenkových operaci mezi dvěma měrenimi byla ověrena chi-kvadrát testem nezávislosti. Výsledky naznačuji, že pozornost studentů je zaměrena predevšim na učitele a že v jejich komentárích prevažuje popis. Po systematické práci $s$ analýzami videonahrávek došlo ke kvalitativnim změnám v subprocesu uvažování založeném na vèdèní. Kvantitativní zmèny spočivaly v délce komentárù, ale i počtu zastoupených kategorii $v$ subprocesu zaměreni pozornosti. Výsledky naznačuji pozitivni posun v profesnim vidèni studentů a jejich zpưsobu premýšleni o vzdèlávaci realitè.
\end{abstract}

Kličová slova: pregraduálni vzděláváni, profesni vidèni, predškolni vzděláváni, student, videonahrávky, zaméreni pozornosti.

Zvýšení kvality vzdělávání na všech stupních škol je předmětem diskuze široké veřejnosti již několik let. $V$ poslední době se však čím dál častěji obrací pozornost také $\mathrm{k}$ předškolnímu vzdělávání (Strategie 2020). Některé české (Syslová \& Hornáčková, 2014), ale i zahraniční výzkumy (Brock, 2012; Friedman, 2007; Saracho \& Spodek, 2003) uka- zují, že pro tak důležité a náročné povolání, jakým je učitelství v mateřských školách, ${ }^{1}$ vzrůstá potřeba mít kvalitní a vysokoškolsky vzdělaný personál. Terciární úroveň vzdělávání však ještě sama o sobě kvalitu nezaručuje (Oberhumer, Schreaer \& Neuman, 2010). Je proto důležité, aby vzdělávání bylo vysoce kvalitní.

\footnotetext{
${ }^{1}$ V souladu s Evropskou unií však také ve školských zařízeních pečujících o děti mladší tř́ let (Syslová, Borkovcová \& Průcha, 2014).
} 
Pedagogické fakulty připravující budoucí učitele proto hledají cesty, jak přípravné vzdělávání zefektivnit (Wiegerová et al., 2015). Ukazuje se, že připravit reflektivního praktika, který „do hloubky přemýšlí o své činnosti (rozhodovacích procesech i konkrétních výukových situacích), analyzuje a hodnotí ji ve vztahu $\mathrm{k}$ zamýšleným cílům a $\mathrm{v}$ širším kontextu vztahů a souvislostí “ (Spilková et al., 2015, s. 8), lze pouze za předpokladu, že bude využívána systematická reflexe jejich zkušeností (Korthagen et al., 2011; Syslová, Horká \& Lazarová, 2014; Vašutová, 2002). S rozvojem reflektivních dovedností studentů učitelství úzce souvisí tzv. profesní vidění.

Záměrem autorky je seznámit čtenáře $s$ výsledky zkoumání povahy profesního vidění studentek oboru Učitelství pro mateřské školy a změnami, které nastaly po systematické reflexi videonahrávek $\mathrm{v}$ předmětu kurikulum předškolního vzdělávání.

\section{TeOretiCKÁ VÝCHOdISKA}

Schopnost identifikovat jevy, které jsou při vzdělávání dětí podstatné, je důležitá jednak pro úspěšný rozvoj profesních dovedností, jednak pro rozvoj profesního myšlení budoucího učitele. $\mathrm{Na}$ co student zaměřuje svoji pozornost, o tom následně přemýšlí. Uvažování o těchto jevech a jeho verbalizace rozvijí pojmový aparát, tj. student prijímá do svého slovníku odbornou terminologii. Zaměření pozornosti na významné aspekty vzdělávacího procesu pomáhá budovat pevné základy pro rozvoj reflektivních dovedností.
V odborné literatuře se v posledních letech stále častěji setkáváme se zkoumáním učitelova pohledu na vzdělávací realitu. Jde např́klad o zkoumání reflektivnich dovedností, at již z pohledu sebe sama jako aktéra vzdělávacího procesu ve třídě (Píšová, 2005; Syslová \& Hornáčková, 2014), nebo z pohledu hodnotitele vzdělávacího procesu jiného učitele (Hsueh \& Tobin, 2003). Dalšími oblastmi výzkumu jsou např́klad schopnost všimnout si (van Es \& Sherin, 2002; Santagata, 2011; Stehlíková, 2010) či profesní viděni (Goodwin, 1994; Minař́íková, 2014).

Často jsou pro zkoumání těchto konceptů využívány videonahrávky. V oblasti předškolního vzdělávání se objevují při zkoumání reflektivních dovedností učitelů ve výzkumech např. Pihlajové a Holstové (2013), Syslové a Hornáčkové (2014). Hsueh a Tobin (2003) využívají videonahrávky ke sledování názorů na respekt $\mathrm{k}$ dítěti u různých profesních skupin. Studie Tsamirové et al. (2014) a Syslové (2015) využívají videonahrávky pro zkoumání konceptu všímání si podstatných aspektů při vzdělávání dětí předškolního věku učiteli mateřských škol, první z nich se zaměřním na rozvoj předmatematických dovedností dětí.

To, co mnohé z těchto výzkumů spojuje, je zaměření na myšlenkové procesy, které při uvažování nad zhlédnutou realitou v mysli učitele probíhají. Tř́dění kvalitativně odlišných úrovní takového uvažování můžeme uvést několik. Naprríklad při zkoumání schopnosti všimnout si rozlišují Sherinová \& van Esová (2009) trri úrovně - popis, vysvětlení a predikce. Píšová (2005) se při zkoumání reflektivnich dovedností 
zaměřila na šest myšlenkových operací popis, analýza, hodnoceni, alternativa, generalizace, metakognice. Stejný počet úrovní, tj. šest, jich při zkoumání profesního vidèní definovala Minař́ková (2014): reprezentováni, interpretováni, vysvètlováni, predikování, hodnoceni a navrhováni alternativ.

Výzkum, který chceme představit $\mathrm{v}$ tomto prríspěvku, směřuje ke konceptu profesního vidění (professional vision), který se v posledních letech etabluje nejen v zahraničí (van Es \& Sherin, 2002; Sonmez \& Hakverdi-Can, 2012), ale i v českém pedagogickém výzkumu (Janík et al., 2014; Minaříková \& Janík, 2012; Vondrová \& Žalská, 2012).

Profesní vidění vnímáme ve shodě s Minaříkovou (2014, s. 754) jako „schopnost učitelů identifikovat aspekty situace relevantní pro její pedagogický úspěch a přemýšlet o nich “, která vychází z pojetí Sherinové (2001). Profesní vidění obsahuje dva subprocesy - výbèrové zaměrené pozornosti (selective attention) a uvažování založené na znalostech (knowledge-based reasoning) (Sherin, 2007, s. 384, in Minaříková \& Janík, 2012). Obě dimenze procesu jsou spolu úzce spjaty a probíhají neoddělitelně. Typy interakcí, kterých si student učitelství všimne, tj. konkrétní projevy dítěte či učitele, $s$ největší pravděpodobností způsob jeho uvažování o určitých jevech ovlivní. Zároveň ale jeho znalosti a přesvědčení do značné míry rozhodují o tom, čeho si v konkrétní situaci všimne.
Předmětem zájmu našeho zkoumání se stal především první ze subprocesů výběrové zaměření pozornosti. Nedal se nicméně oddělit od myšlenkových procesů, které se v komentárích studentek promítaly. To, jakým způsobem studentky o sledovaných jevech přemýšlely, již zasahuje spíše do uvažování založeného na znalostech.

Pro zkoumání způsobu uvažování o zhlédnuté realitě jsme zvolili kategoriální systém Minaříkové (2014, s. 757), který obsahuje tyto kategorie:

- Popis vnímáme jako objektivní záznam reality; jde o popisování situací, které lze na videonahrávce zachytit.

- Interpretováním chápeme studentovo porozumění situaci, odhad jevů a vztahů mezi jevy, které nelze př́mo pozorovat, které jsou založeny spišse na tacitních znalostech. ${ }^{2}$

- Vysvětlování využívá obecné principy založené na teoretických znalostech (Teorii i teorii), ${ }^{3}$ které vyjadřují porozumění dané situaci.

- Predikování je odhad důsledků situace, tzn. jak by jednání učitele mohlo ovlivnit výsledky vzdělávání či jednotlivé děti.

- Hodnocením rozumíme zaujetí postoje ke zhlédnuté realitě, a to jak pozitivního, tak i negativního.

- Návrhy alternativních postupĩ chápeme jako návrhy jiných postupů, které by byly vhodnější nebo také možné.

\footnotetext{
$\overline{2}$ Jde o znalosti vycházející z individuální zkušenosti každého jedince (Švec, 2012). Tacitní znalosti jsou velmi úzce svázány s hodnotami, emocemi, ale také idejemi každého z nás. Někdy se o tacitních znalostech hovoří také jako o „tichých“ či „skrytých“.

${ }^{3}$ Podrobněji Korthagen et al., 2011, s. 27.
} 


\section{SEMINÁř ZaMĚŘENÝ NA ROZVOJ PROFESNÍHO VIDĚNÍ}

Seminář Kurikulum předškolního vzdělávání je povinným předmětem ve třetím semestru oboru Učitelství pro mateřské školy. $\mathrm{V}$ jeho průběhu byla využita výuková videa (Chaloupková \& Syslová, 2015), která vznikla v rámci projektu Rozvojem osobnostnich a profesnich kompetencí učiteli $M S ̌$ a ZŠ k vyšši kvalitě vzdèlávání (CZ.1.07/1.3.00/48.0022). Semináři jsou věnovány dvě hodiny týdně a téměř $\mathrm{v}$ každé $\mathrm{z}$ nich byla využita některé $\mathrm{z}$ výukových videí. $\mathrm{V}$ rámci videonahrávek byly prezentovány sekvence, které souvisejí s projektováním a realizací vzdělávání v mateřské škole, např. způsob komunikace učitelky s dítětem, motivace dětí, použité organizační formy, využití prožitkového způsobu učení či modelu učení E-U-R (evokace, uvědomění, reflexe). Sledovány a diskutovány byly především strategie vedoucí $\mathrm{k}$ rozvoji kompetencí dětí a soulad cílů a obsahu.

Videonahrávky přinášejí do výuky na vysoké škole realitu, která poskytuje prostor pro propojování teorie $s$ praxí v rámci př́ípravného vzdělávání. Pro podporu rozvoje profesního vidění a profesního myšlení byly názory studentek po zhlédnutí videonahrávky vzájemně konfrontovány, následně se o jejich obsahu diskutovalo s vysokoškolským učitelem, respektive diskuze se opíraly o metodické publikace vztahující se $\mathrm{k}$ individualizovanému předškolnímu vzdělávání (např. Krejčová, Kargerová \& Syslová, 2015) a studentkám byly doporučeny $\mathrm{k}$ ústní zkoušce $\mathrm{v}$ předmětu Předškolní pedagogika. Jeho zakončení je prerekvizitou pro absolvování předmětu Kurikulum předškolního vzdělávání. Výuková videa a otázky pomáhají studentkám $s$ identifikací možných přístupů $\mathrm{v}$ předškolním vzdělávání, pochopením procesů učení dětí a diferenciací vzdělávací nabídky.

Seminár je propojen $s$ pedagogickou praxí, na níž studentky realizují samostatné výstupy. Jedním z úkolů, které na praxi plní, je libovolný výstup nahrát a na jeho základě vytvořit asi pětiminutovou prezentaci. Svůj výstup písemně vyhodnocují (provádějí sebereflexi) a zasílají jej vysokoškolskému učiteli. Poté se studentky setkávají ve skupinách po šesti, jde o tzv. supervizni skupinové setkání (Korthagen et al., 2011 s. 117), a svoje videonahrávky prezentují. Po jejich zhlédnutí mají za úkol výstupy ostatních kriticky zhodnotit. Vyhledávají pozitivní momenty a navrhují další možné způsoby práce s dětmi.

Vyučující vstupuje do rozboru videonahrávky $\mathrm{v}$ roli supervizora ${ }^{4} \mathrm{a} \mathrm{v}$ prŕṕpadě potřeby využívá otázky, které posilují percepční schopnosti studentek, schopnost

\footnotetext{
$\overline{{ }^{4} J d e ~ o ~ p r u ̊ v o d c e, ~ k t e r y ́ ~ p o m a ́ h a ́ ~ s u p e r v i d o v a n e ́ m u ~ t y ́ m u ~(v ~ t o m t o ~ p r ̌ ́ i ́ p a d e ̌ ~ s k u p i n e ̌ ~ s t u d e n t e k) ~ p r ̌ i ~ r e f l e k t o v a ́ n i ́ ~}$ prezentovaných videonahrávek. Pomoc spočívá v prohloubení lepš́ho porozumění vzdělávacích situací, umožňuje rozvoj nových perspektiv profesního jednání (Korthagen et al., 2011, s. 117-131). Převažuje konzultativní dialogický charakter supervize, v němž převládá usuzování na různé možnosti (Janík \& Minaříková et al., 2011, s. 28). Supervize se současně stává modelem učení, ukazuje, že sdílení mezi učitelkami se může stát v MŠ prostředkem ke zvýšení kvality a efektivity jejich práce (Syslová et al., 2016).
} 
analyzovat interakce mezi studentkou a dítětem, didaktické obsahy (naplnění cílů, vhodnost zvolených metod apod.), ale i postoje (důvody volby, pocity atd.). Např́klad „Co jste chtěla u dětí rozvíjet?“ „Ŕíkáte, že jste chtěla podpořit rozvoj tvořivosti, a já jsem slyšela, že dítěti ř́káte, co má udělat...", „Co děti dělaly a co se u toho mohly naučit?" (Syslová et al., 2014a, s. 90).

$\mathrm{V}$ následujícím textu přibližíme změny $\mathrm{v}$ profesním vidění studentek oboru Učitelství pro mateřské školy po absolvování předmětu Kurikulum předškolního vzdělávání, jak jsme je zachytili v našem výzkumu.

\section{Metodologie VÝZKUMU}

Výzkumný vzorek tvořilo 18 studentek oboru Učitelství pro mateřské školy Pedagogické fakulty Masarykovy univerzity. Jednalo se o všechny studentky přítomné na obou seminárích, ve kterých došlo ke sběru dat. Výzkum byl veden následujícími otázkami:

1. Čeho si studenti všímají ve vybrané videosekvenci?

2. Jak o zhlédnutých jevech přemýšlejí (které subprocesy uvažování založeného na vědění využívají)?

3. Jak se změnilo zastoupení, resp. struktura jejich komentáŕủ po systematické reflexi videonahrávek?

\subsection{Sběr dat a jejich analýza}

Sběr dat proběhl ve dvou fázích. První se uskutečnila na začátku jarního semest- ru v prvním semináři předmětu Kurikulum předškolního vzdělávání. Úkolem studentek bylo pozorovat pětiminutovou videonahrávku a následně splnit uvedený pokyn: „Okomentujte zhlédnutou videonahrávku na připravený list papíru." Videonahrávkou bylo jedno z videí pořízených $\mathrm{v}$ rámci jiného výzkumného šetření. Respondentka zmíněného výzkumu s jejím zveřejněním vyjádřila souhlas, nebot videozáznam poskytuje ukázku kooperativních činností, které nejsou $\mathrm{v}$ mateřských školách příliš často $\mathrm{k}$ vidění (ČŠI, 2015, s. 31).

Popis videonahrávky:

Videonahrávka zachycuje dèti sedící $v$ kruhu společnès učitelkou. Ta je informuje, že pro ně má prippravený úkol. Následuje zadáni: "Udělejte si pèt skupinek. "Dèti vytváreji skupiny a teprve poté pricházi zadáni úkolu, jehož cílem je, aby dèti společně vybraly a následnè ztvárnily libovolné pismeno. Déti se rozcházeji po trídè a pracují. $Z$ videonahrávky lze vypozorovat, že učitelka pravidelně procházi trídou a poskytuje dètem zpètnou vazbu, prípadně korekci jejich aktivit až ke splnèni úkolu. Videonahrávka konči v momentě, kdy všechny dèti uléhaji do kruhu, hraje hudba a dèti relaxuji.

$\mathrm{V}$ průběhu semestru se už studentky $s$ touto videonahrávkou nesetkaly, viděly ji opět až na začátku dalšího semestru na společném setkání $\mathrm{k}$ souvislé praxi, tedy $s$ odstupem sedmi měsíců. Jejich nestrukturované písemné narace byly přepsány do programu Atlas.ti. Analýza dat probíhala ve dvou krocích. Pro zodpovězení první výzkumné otázky Čeho si 
studenti všimají..? bylo využito kategoriálního systému (Syslová, 2015). Při prvním ověrování kategoriálního systému byla zjištována shoda mezi dvěma pozorovateli/výzkumníky na $10 \%$ výzkumného vzorku. Byla určována přímá shoda $\mathrm{v}$ procentech, ale nebyla dostatečná (73\%). Původních 11 kategorií bylo zúženo na pět. Při druhém ověrení reliability dosáhla př́má shoda $86 \%$. Kategorie jsou disjunktní. Jde o oblasti/kategorie projevy učitelky, didaktické aspekty, činnosti dètí, relaxace a kontext vzděláváni (viz tab. 1). Obsahem první kategorie (projevy učitelky) byly výroky týkající se verbálních i neverbálních projevů učitelky, ale také jejího pohybu po trrídě. Kategorie didaktické aspekty zahrnovala organizační formy, zaměření činností a jejich typy. Komentáře týkající se činností dětí reflektovaly jejich reakce na pokyny učitelky, tj. jak se chovaly, co ř́kaly. Relaxace se v komentárích studentek jevila jako specifická kategorie, nebot́ vyplňovala čas po ukončování činností jednotlivých skupin, a proto se stala samostatnou kategorií. Do kategorie kontext vzdělávání byly zařazeny komentáŕe, které nemohly být součástí žádné z uvedených kategorií. V první etapě sběru dat šlo např. o komentář: Déti mély dostatek času k ukončeni činnosti, v druhé etapě např.: Vyzdobení prostoru trídy výtvory dètí.

Při kódování byly komentáře studentek nejprve rozděleny na jednotky kódování podle jednotlivých kategorií. Kódován byl vždy takový úsek textu, který spadal pouze do jedné kategorie v použitém kategoriálním systému. Znamená to, že někdy musely být věty rozděleny na více částí, př́padně z nich bylo vyňato slovo, které již patřilo do jiné kategorie. Pro jejich vymezení uvádíme prríklady výroků studentek kurzívou:

Projevy učitelky: Učitelka klade otázky $k$ řešeni problémí.

Didaktické aspekty: Cinnosti jsou polořizené.

Činnosti dětí: Skupina klukù se rozhodla jako prvni, které pismeno bude dělat.

Relaxace: Kdo je hotový, relaxuje.

Kontext vzdělávání: Prostor je vyzdoben výtvory dètí (mašle, strom).

Ve druhém kroku byly výroky studentek analyzovány podle předem stanoveného kategoriálního systému (Minaříková, 2012, s. 140-143) a směřovaly k odpovědi na druhou výzkumnou otázku: Jak studenti o zhlédnutých jevech premýšleji? Pro vymezení kategoriálního systému, který definuje subprocesy uvažování založeného na vědění, uvádíme prríklady výroků studentek kurzívou:

Popis: Učitelka prí rozhovoru s dètmi snižuje polohu.

Interpretování: Znalost dètí a jejich rodinného zázemí.

Vysvětlování: Moc složité zadání, nèkterým dètem to může dělat velké problémy (jestliže neumi počitat do 5, neznaji tvar pismene).

Predikování: Zadáni děti privedlo $k$ domlouváni a spolupráci.

Hodnocení: Rozděleni do skupin bylo prílišs náročné.

Návrh alternativních postupů: Pokyn "musite se domluvit" bych zmènila na "zkuste se domluvit“. 
Poslední krok se vztahoval k třetí výzkumné otázce, která je zaměřena na změny, které v komentárích studentů nastávají po systematické práci s videonahrávkami. Nejprve byly celé komentáře jednotlivých studentek porovnávány. Následně bylo zjištováno chí-kvadrát testem, zda jsou rozdíly ve druhém a třetím ročníku významné.

\section{VÝZKUMNÁ ZJIŠTĚNí}

Výzkumná zjištění jsou organizována podle výzkumných otázek: a) čeho si studenti všímají, b) jak o zhlédnutých jevech přemýšlejí, c) ke kterým změnám během času došlo.

\section{1 Čeho si studentky všímají}

Zaměření pozornosti studentek se $\mathrm{v}$ převážné většině orientovalo na učitele (viz tab. 1). V tabulce jsou zaznamenány jak absolutní počty kódů (úseků komentářů), které spadají do jednotlivých kategorií, tak relativní četnosti v procentech, aby bylo možné lépe porovnat jejich zastoupení v obou fázích sběru dat. Při jejich detailnější analýze můžeme v kategorii Projevy učitele nalézt další subkategorie. Při prvním sběru dat se studentky nejčastěji zaměřovaly na zadávání úkolu a ověřování jeho pochopení stejně jako na neverbální projevy učitelky. $Z$ neverbálních projevů učitelky se jednalo o komentáře zaměřené na snižování polohy učitelky a její oční kontakt s dětmi. Další subkategorií se stejným počtem jednotek byla podpora spolupráce, poskytování zpětné vazby dětem a vyjadřování důvěry $\mathrm{v}$ jejich schopnosti. Co do četnosti se na třetím místě objevily subkategorie týkající se pohybu učitelky po třídě, její charakteristiky (klidná, nervózní) a práce $s$ hlasem (přiměřený, polohlasně). Zbytek výroků již byl velmi specifický a nedal se přriřadit k žádné subkategorii.

Také v ostatních kategoriích lze najít další subkategorie. $V$ této studii však není prostor pro jejich detailnějšś analýzu. V druhé fázi sběru dat se struktura obsahu komentářů nijak výrazněji nezměnila.

\subsection{Jak studentky o zhlédnutých jevech přemýšlejí}

Nejčastěji byly $\mathrm{v}$ komentárích studentek zastoupeny popisy a interpretacemi (viz tab. 3). V tabulce jsou zaznamenány jak absolutní počty kódů (úseků komentářů), které spadají do jednotlivých kategorií, tak relativní četnosti $\mathrm{v}$ procentech, aby bylo možné lépe porovnat jejich zastoupení v obou fázích sběru dat. Třetí nejčastější myšlenkovou operací bylo hodnocení. V první etapě výzkumu šlo $\mathrm{v}$ převážné většině o kritiku práce učitele. $Z$ celkového počtu 22 hodnoticích výroků byly pouze tři pozitivní, např. „potom je ale učitelka hezky uklidnila hudbou“. Nejčastěji patřila kritika složitosti zadání („Rozdělit se do pěti skupinek je podle mě pro děti složité.“), několikrát se objevilo také negativní hodnocení nadměrného používání zdrobnělin („Příliš časté používání zdrobnělin - ,zádíčka, písmenka."'). Stejně jako studentky kritizovaly $\mathrm{v}$ převážné většině způsob zadání úkolu dětem, 
tak se v alternativních návrzích objevovaly většinou návrhy na jiné rozdělení do skupin a zadání úkolu - např. Zvolila bych kapitána, kterého bych dala do jedné cásti mistnosti. Požádala bych dèti, at'se rozdèli tak, aby jich byl v každé skupině stejný počet. Nerekla bych, aby si pismenko vybraly - každé skupinè bych dala papir s jedním pismenem.

\subsection{K jakým změnám došlo po systematické reflexi videonahrávek}

Na první pohled je patrné, že došlo ke kvantitativním změnám, tzn. že se zvýšil počet jednotek $\mathrm{v}$ jednotlivých komentáŕích. Na začátku kurzu byl nejnižší počet jednotek u studentky 17 , a to dvě, přičemž jejich průměrný počet na studentku činil šest jednotek. Po skončení kurzu byl nejnižší počet jednotek, tj. šest, u studentek 15, 17 a 18 , průměrný počet na studentku činil devět jednotek. Průměrný nárůst jednotek se pohyboval okolo tř́ jednotek na jednu studentku. Došlo však $\mathrm{k}$ velmi individuálním odchylkám, např. u studentek 4 a 8 nedošlo $\mathrm{k}$ žádným posunům, naopak u studentky 5 došlo $\mathrm{k}$ posunu o osm jednotek.

Studentky zaznamenávaly komentáře zpravidla $\mathrm{v}$ časové souslednosti, což se $s$ odstupem času př́liš nezměnilo. Toto zjištění je $v$ souladu $s$ dalšími výzkumy profesního vidění studentů, $\mathrm{v}$ nichž se také ukázalo, že události komentují, jak jdou v čase (van Es \& Sherin, 2002).

V komentárích studentek se po kurzu objevily nové komentáře, respektive došlo $\mathrm{k}$ posunu pozornosti od dětí a učitelky také k prostoru, což se v první etapě sběru dat nestalo. Např́iklad vyzdobeni prostoru trídy výtvory dètí; kouty, které nejsou otevrené. Konkrétnější byly také komentáře činnosti dětí (např. skupina klukư se rozhodla jako první). V první etapě popisy činností dětí i učitelky splývaly (např. učitelka použila konkrétni príklad ze života ditěte). Nově se v komentárích týkajících se projevů učitele objevilo slovní spojení problémové otázky.

U tří studentek (9, 16 a 17) jsme v první fázi sběru dat identifikovali $100 \%$ zaměření pozornosti na učitelku. Při druhém sběru dat byly u všech studentek zastoupeny $\mathrm{v}$ komentárích alespoň dvě kategorie.

Zda jsou rozdíly $\mathrm{v}$ zaměření pozornosti před kurzem a po jeho skončení významné (viz tab. 2), jsme zjištovali chí-kvadrát testem, sledovali jsme vztah dvou nominálních proměnných. Stanovili jsme si jednak nulovou hypotézu: „H0: Výběrové zaměření pozornosti se před kurzem a po kurzu neliší", jednak alternativní hypotézu: „H1: Výběrové zaměření pozornosti se před kurzem a po kurzu liší“. Zvolená hladina významnosti je 0,05. Předpokladem pro tento test je splnění podmínek dobré aproximace. Tedy $80 \%$ očekávaných četností musí být vyšší než 5 a zbylých $20 \%$ nesmí klesnout pod 2 (Budíková, Králová \& Maroš, 2010, s. 214).

Tabulka 1 popisuje absolutní počty kombinací proměnné charakterizující výběrová zaměření pozornosti před kurzem a po kurzu, dále také sloupcově podmíněné relativní četnosti v procentech. 
Tab. 1. Kontingenční tabulka četností zaměření pozornosti

\begin{tabular}{|l|c|c|c|}
\hline \multirow{2}{*}{ Výběrové zaměření pozornosti } & \multicolumn{3}{|c|}{ Dvojrozměrná tabulka: Pozorované četnosti } \\
\cline { 2 - 4 } & Před kurzem & Po kurzu & Rádkové součty \\
\hline Projevy učitele & 68 & 110 & 178 \\
\hline Sloupcově podmíněná četnost & $62 \%$ & $67 \%$ & \\
\hline Didaktické aspekty & 15 & 16 & 31 \\
\hline Sloupcově podmíněná četnost & $14 \%$ & $10 \%$ & \\
\hline Činnosti dětí & 13 & 21 & 34 \\
\hline Sloupcově podmíněná četnost & $12 \%$ & $13 \%$ & \\
\hline Relaxace & 10 & 11 & 21 \\
\hline Sloupcově podmíněná četnost & $9 \%$ & $7 \%$ & \\
\hline Kontext & 4 & 5 & 9 \\
\hline Sloupcově podmíněná četnost & $4 \%$ & $3 \%$ & \\
\hline Celkem & 110 & 163 & 273 \\
\hline
\end{tabular}

V tabulce 1 vidíme, že podíly výběrových zaměření se před kurzem a po kurzu prríliš neliší. Zaměření na projevy učitele se po kurzu zvýšilo stejně jako zaměření na činnost dětí. Ostatní zaměrení pozornosti se po kurzu naopak snížila.
Podmínky dobré aproximace byly splněny. Pearsonův chí-kvadrát test ukázal, že p-hodnota testu je 0,7797 . Je tedy vyšší než zvolená hladina významnosti. S 5\% rizikem omylu se nám nepodařilo prokázat, že se výběrová zaměření pozornosti před kurzem a po kurzu liší.

Tab. 2. Očekávané četnosti zaměření pozornosti

\begin{tabular}{|l|c|c|c|}
\hline \multirow{2}{*}{ Výběrové zaměření pozornosti } & \multicolumn{3}{|c|}{ Dvojrozměrná tabulka (shrnutí): Očekávané četnosti } \\
\cline { 2 - 4 } & Před kurzem & Po kurzu & Rádkové součty \\
\hline Projevy učitele & 71,72 & 106,28 & 178,00 \\
\hline Didaktické aspekty & 12,49 & 18,51 & 31,00 \\
\hline Činnosti dětí & 13,70 & 20,30 & 34,00 \\
\hline Relaxace & 8,46 & 12,54 & 21,00 \\
\hline Kontext & 3,63 & 5,37 & 9,00 \\
\hline Celkem & 110,00 & 163,00 & 273,00 \\
\hline
\end{tabular}


Pokud se podíváme na subprocesy uvažování studentek (tab. 3), můžeme vidět, že se po kurzu výrazně zvýšil podíl popisu, a naopak snízil podíl interpretování a hodnocení. Zda jsou rozdíly v zaměření pozornosti před kurzem a po kurzu významné (tab. 4), jsme zjištovali chí-kvadrát testem. Sledovali jsme vztah dvou nominálních proměnných. Stanovili jsme si nulovou hypotézu: „H0: Zastoupení subprocesů uvažování založeného na vědění se před kurzem a po kurzu neliš́ı “ a alternativní hypotézu: „H1: Zastoupení subprocesů uvažování založeného na vědění se před kurzem a po kurzu liší“. Zvolená hladina významnosti je 0,05 .

Tabulka 4 popisuje absolutní počty kombinací proměnné popisující subpro- cesy uvažování před kurzem a po kurzu, dále také sloupcově podmíněné relativní četnosti v procentech.

Předpokladem pro tento test je splnění podmínek dobré aproximace.

$\mathrm{Z}$ důvodu nesplnění podmínek dobré aproximace bylo ze subprocesů vyřazeno vysvětlování a predikování. Vykazovaly nejnižší očekávané četnosti. Poté již očekávané četnosti splňovaly podmínky pro test. Pearsonův chí-kvadrát test ukázal, že p-hodnota testu je 0 . Je tedy nižší než zvolená hladina významnosti. S 5\% rizikem omylu se nám podařilo prokázat, že se zastoupení subprocesů uvažování založeného na vědění před kurzem a po kurzu významně liší.

Tab. 3. Kontingenční tabulka četností subprocesů uvažování

\begin{tabular}{|l|c|c|c|}
\hline \multirow{2}{*}{ Zastoupení subprocesů uvažování } & \multicolumn{3}{|c|}{ Dvojrozměrná tabulka: Pozorované četnosti } \\
\cline { 2 - 4 } & P̌̌ed kurzem & Po kurzu & Řádkové součty \\
\hline Popis & 44 & 121 & 165 \\
\hline Sloupcově podmíněná četnost & $40 \%$ & $72 \%$ & \\
\hline Interpretování & 31 & 23 & 54 \\
\hline Sloupcově podmíněná četnost & $28 \%$ & $14 \%$ & \\
\hline Vysvětlování & 3 & 2 & 5 \\
\hline Sloupcově podmíněná četnost & $3 \%$ & $1 \%$ & \\
\hline Predikování & 4 & 4 & 8 \\
\hline Sloupcově podmíněná četnost & $4 \%$ & $2 \%$ & \\
\hline Hodnocení & 22 & 11 & 33 \\
\hline Sloupcově podmíněná četnost & $20 \%$ & $7 \%$ & \\
\hline Návrh alternativních postupů & 5 & 6 & 11 \\
\hline Sloupcově podmíněná četnost & $5 \%$ & $4 \%$ & \\
\hline Celkem & 109 & 167 & 276 \\
\hline
\end{tabular}


Tab. 4. Očekávané četnosti subprocesů uvažování

\begin{tabular}{|l|c|c|c|}
\hline \multirow{2}{*}{ Zastoupení subprocesů uvažování } & \multicolumn{3}{|c|}{ Dvojrozměrná tabulka (shrnutí): Očekávané četnosti } \\
\cline { 2 - 4 } & Před kurzem & Po kurzu & Řádkové součty \\
\hline Popis & 65,16 & 99,84 & 165,00 \\
\hline Interpretování & 21,33 & 32,67 & 54,00 \\
\hline Vysvětlování & 1,97 & 3,03 & 5,00 \\
\hline Predikování & 3,16 & 4,84 & 8,00 \\
\hline Hodnocení & 13,03 & 19,97 & 33,00 \\
\hline Návrh alternativních postupů & 4,34 & 6,66 & 11,00 \\
\hline Celkem & 109,00 & 167,00 & 276,00 \\
\hline
\end{tabular}

\section{ZÁVĚRY A DISKUSE}

Představená studie si kladla za cíl seznámit čtenáře $s$ výsledky zkoumání povahy profesního vidění studentů učitelství pro mateřské školy a změn, které nastaly po systematické reflexi videonahrávek $\mathrm{v}$ předmětu Kurikulum předškolního vzdělávání.

Výsledky naznačují, že u studentek došlo ke změnám jak kvantitativním, tak i kvalitativním. Kvantitativní změny představují obrat $\mathrm{v}$ délce komentářů, respektive počtu jednotek, který se ve druhé fázi sběru dat zvýšil v průměru o tři jednotky u studentky. Zaměření pozornosti se u jednotlivých studentek zvýšilo také v počtu zastoupení jednotlivých kategorií a rozšriríilo se o komentáŕe zaměřené na prostředí třídy. Ty se v první fázi sběru dat neobjevily vůbec. Ke statisticky významným změnám však u zaměření pozornosti nedošlo. Studentky se stále orientovaly nejvíce na projevy učitelky, což je v souladu s dalšími nálezy (Syslová, 2015), přestože šlo o učitele mateřských škol.

Orientaci studentek na zadávání úkolu (pozn. subkategorie projevů učitele) můžeme považovat za pozitivní zjištění, nebot je klíčové pro učení dětí. Autorky obdobného výzkumu Vondrová a Žalská (2015, s. 98) přesto, že se jednalo o studenty oboru Matematika, došly $\mathrm{k}$ velmi podobným závěrům jako výzkumný kolektiv (Tsamir et al., 2014, s. 38), který zkoumal zaměření pozornosti u předškolních pedagogů. Sledování detailů videonahrávky pomáhá vyhodnotit znalosti a dovednosti dítěte a diferencovat úkol $\mathrm{k}$ jeho aktuálním možnostem.

Bylo by jistě zajímavé sledovat detailněji komentáře studentek zaměřené na zadávání úkolů. Je možné, že bychom dospěli ke stejným závěrům jako Minař́ková (2014, s. 772) přesto, že i v tomto výzkumu se stali zkoumaným souborem studenti oboru Anglický jazyk (tedy studenti připravující se na práci na vyšších 
stupních škol, než je předškolní a primární). Ta v závěru uvádí, že „v oblasti zadávání instrukcí se výběrové zaměření pozornosti soustředilo především na učitele a na vyučovací procesy, méně pak na žáky a jejich reakce“.

Co se týká subprocesů uvažování založeného na vědění, došlo $\mathrm{v}$ uvažování studentek ke statisticky významným změnám. Mnohem častěji byl zastoupen věcný popis, což se změnou v kvantitě přináší pozitivní zjišstění, že studenti si všímali více aspektů vzdělávání, $s$ čímž koresponduje také snížení interpretací studentek, které $\mathrm{v}$ první etapě směřovalo spíše $\mathrm{k}$ tacitním znalostem (Švec, 2012) než k uvažování založeném na „vědění“.

Za pozitivní můžeme označit také mnohem méně kritiky v subprocesu hodnocení. Některé výzkumy (Vondrová \& Žalská, 2012; 2015) potvrzují, že nedostatek zkušeností a teoretických znalostí vede studenty $\mathrm{k}$ větší kritice zhlédnuté reality. Stejně jako Vondrová \& Žalská (2015) si uvědomujeme, že bude nutné pracovat $s$ popisy pedagogických situací zhlédnutých na videonahrávkách v souladu $s$ explicitně vyslovenými teoretickými koncepty.

$\mathrm{V}$ souvislosti $s$ alternativními návrhy nás vede k zamyšlení skutečnost, proč některé studentky kritizovaly způsob rozdělení dětí do skupinek a navrhovaly změny zadání, když podle slov jedné $\mathrm{z}$ nich dèti reagovaly rychle a nenastal žádný problém, že by se některé $z$ dètí nezaŕadilo, dokonce oceňovala, že se dèti dokázaly domluvit. Může to znamenat, že studentky dostatečně nezvažují souvislosti mezi tím, co a jakým zpo̊sobem učitelka říká, a tím, jak děti na její pokyny reagují.

Naše studie, podobně jako další výzkumy (srov. Minař́ková, 2014; van Es \& Sherin, 2002; Vondrová \& Žalská, 2015), ukázala, že systematická práce $\mathrm{v}$ rámci př́ípravného učitelského vzdělávání může způsobit změny v profesním vidění, resp. uvažování založeném na vědění. Přestože jde o výzkumy, které se netýkají studentů oboru Učitelství pro mateřské školy, lze očekávat, že dopady budou obdobné. Popis pomáhá studentkám detailněji proniknout do podstaty pedagogických situací a následně je lépe analyzovat. Naopak je odvádí od unáhlených, povrchních a zpravidla kritických soudů. Přesto však u studentek nedošlo $\mathrm{k}$ využívání vyšších hladin uvažování, jakými jsou např. vysvětlování a predikování. Bude tedy nutné hledat další cesty, jak podpořit studentky $\mathrm{k}$ hlubší analýze viděného.

Zjišsění mají však svá omezení. Změny kvantitativní i kvalitativní mohly být způsobeny efektem opakovaného zhlédnutí videonahrávky v krátkém časovém úseku, kde mohla významnou roli sehrát pamět. Limitující je také malý vzorek - počet studentek je př́liš nízký, aby bylo možné dělat obecnější závěry. Bude nutné provést další výzkumy, které by eliminovaly tyto limity. Jisté omezení mohlo způsobit také př́iliš obecné zadání úkolu. Pokud by bylo zadání konkrétnější, např. „Zamyslete se nad zhlédnutou videonahrávkou a vyhodnotte ji“", mohlo by studenty motivovat k hlubší analýze.

Výsledky vyvolávají otázky, zda je možné zvýšit zaměření pozornosti stu- 
dentek na dítě. To by jim mohlo pomoct jak v rozvoji diagnostických dovedností, tak i ve schopnosti lépe analyzovat dopady chování a jednání učitele na výsledky vzdělávání, tedy na rozvoj dítěte, tak jak je to prezentováno např̀ ve videoklubech van Esové \& Sherinové (2010, s. 169) či Janíka et al. (2016, s. 133). Žrejmě by bylo také vhodné více se zajímat o důvody zvýšené kritiky studentek, např́íklad ve vztahu k obsahům komentáŕù, jak uvádí Vondrová a Žalská (2015, s. 98).

\section{Literatura}

Budíková, M., Králová, M., \&,Maroš, B. (2010). Průvodce základními statistickými metodami. Praha: Grada.

Brock, A. (2012). Building a model of early years professionalism from practitioners' perspectives. Journal of Early Childhood Research, 11(1) 27-44.

ČŠI (2015). Výroční zpráva České školni inspekce za školni rok 2014/2015. Praha: ČŠI. Dostupné z http://www.csicr.cz/html/VZ2014-15v2/flipviewerxpress.html

Friedman, R. (2007). Listening to children in the early years. In M. Wild \& H. Mitchell (Eds.), Early childhood studies: Reflective reader (s. 81-94). Exeter: Learning Matters.

Goodwin, C. (1994). Professional vision. American Anthropologist, 96(3), 606-633.

Hsueh, Y., \& Tobin, J. (2003). Chinese early childhood educators' perspectives on dealing with a crying child. Journal Early Childhood rearerch, 1(1), 73-94.

Chaloupková, L., \& Syslová, Z. (2015). Rámec profesnich kvalit učitele mateřské školy. Výuková videa. Brno: Masarykova univerzita. Dostupné z https://munispace.muni.cz/index.php/ munispace/catalog/book/551

Janík, T., et al. (2014). Profesní vidění u učitelů: pokus o zmapování výzkumného pole. Pedagogika, 64(2), 151-176.

Janík, T., Minaříková, E., Píšová, M., Uličná, K., \& Janík, M. (2016). Profesni viděni učiteli a jeho rozvijeni prostřednictvím videoklubü. Brno: Masarykova univerzita.

Janík, T., \& Minaříková, E., et al. (2011). Video v učitelském vzdělávání. Teoretická východiska - aplikace-výzkum. Brno: Paido.

Korthagen, F., et al. (2011). Jak spojit praxi s teorii: didaktika realistického vzdèláváni učitelì. Brno: Paido.

Krejčová, V., Kargerová, J., \& Syslová, Z. (2015). Individualizace předškolního vzdělávání. Praha: Portál.

Minaříková, E. (2012). Povaha profesního vidění u studentů učitelství anglického jazyka teoretická východiska a metodologie. In T. Janík \& K. Pešková et al., Školni vzdèlávání: podmínky, kurikulum, aktérí, procesy, výsledky (s. 131-147). Brno: Masarykova univerzita.

Minaříková, E. (2014). Profesní vidění studentů učitelství anglického jazyka: jak vidí studenti výukové situace zachycené na videu? Pedagogická orientace, 24(5), 753-777.

Minaříková, E., \& Janík, T. (2012). Profesní vidění učitelů: od hledání pojmu k možnostem jeho uchopení. Pedagogická orientace, 22(2), 181-204. 
Oberhuemer, P., Schreyer, I., \& Neuman, M. J. (2010). Professionals in early childhood education and care systems. European profiles and perspectives. Opladen \& Farminghton Hills: Barbara Budrich.

Pihlaja, M. P., \& Holst, T. K. (2013). How reflective are teachers? A study of kindergarten teachers' and special teachers' levels of reflection in day care. Scandinavian Journal of Educational Research, 57(2), 182-198.

Píšová, M. (2005). Klinický rok: Procesy profesního rozvoje studentů učitelstvi a jejich podpora. Pardubice: Univerzita Pardubice.

Santagata, R. (2011). From teacher noticing to a framework for analyzing and improving classroom lessons. In M. S. Sherin, V. R. Jacobs \& R. A. Philipp (Eds.), Mathematics Teacher Noticing (s. 152-168). New York: Routledge.

Saracho, O., \& Spodek, B. (2003). Studying teachers in early childhood settings. Charlotte, VA: Information Age Publishing.

Sherin, M. G. (2001). Developing a professional vision of classroom events. In T. Wood, B. S. Nelson \& J. Warfeld (Eds.), Beyond classical pedagogy: Teaching elementary school mathematics (s. 75-93). Hillsdale: Erlbaum.

Sherin, M. G. (2007). The development of teachers' professional vision in video clubs. In R. Goldman, R. Pea, B. Barron \& S. J. Derry (Eds.), Video research in the learning sciences (s. 383-395). London: Lawrence Erlbaum Associates Publishers.

Sherin, M. G., \& van Es, E. A. (2009). Effects of video club participation on teachers' professional vision. Journal of Teacher Education, 60(1), 20-37.

Sonmez, D., \& Hakverdi-Can, M. (2012). Videos as an instructional tool in pre-service science teacher education. Egitim Arastirmalari-Eurasian Journal Of Educational Research, 12(46), 141-158.

Spilková, V., et al. (2015). Klinická škola a její role ve vzděláváni učitelỉ. Praha: Retiga.

Stehlíková, N. (2010). Interpretace některých didakticko-matematických jevů u studentů učitelství a u učitelů matematiky. Pedagogika, 60(3-4), 303-313.

Syslová, Z. (2015). Jak učitelé mateřských škol vnímají edukační realitu. In A. Wiegerová et al. Profesionalizace učitele mateřské školy z pohledu reformy kurikula (s. 37-48). Zlín: Univerzita Tomáše Bati ve Zlíně.

Syslová, Z., et al. (2016). Proména mateřské školy v učici se organizaci. Praha: Wolters Kluwer. Syslová, Z., Borkovcová, I., \& Průcha, J. (2014). Péce a vzděláváni dètí v raném věku. Praha: Wolters Kluwer.

Syslová, Z., Horká, H., \& Lazarová, B. (2014a). Od teorie prééškolního vzděláváni k praxi $v$ mateŕské škole. Brno: Masarykova univerzita.

Syslová, Z., \& Hornáčková, V. (2014). Kvalita reflexe v profesním myšlení učitelek mateřských škol. Pedagogická orientace, 24(4), 535-561.

Švec, V. (2012). Sdílení tacitních znalostí ve vzdělávání učitelů jako pohyb od teorie k praxi a zpět. In J. Kohnová et al. Profesní rozvoj učitelì a cíle školního vzdèláváni (s. 99-110). Praha: Univerzita Karlova. 
Tsamir, P., et al. (2014). Task design and implementation as a two-way activity: The case of preschool teachers. Scientia in Educatione, 5(2), 30-39.

van Es, E. A., \& Sherin, M. G. (2002). Learning to notice: Scaffolding new teachers' interpretations of classroom interactions. Journal of Technology and Teacher Education, 10(4), 571-596. van Es, E. A., \& Sherin, M. G. (2010). The influence of video clubs on teachers' thinking and practice. Journal of Mathematics Teacher Education, 113(2), 55-176.

Vašutová, J. (2002). Strategie výuky ve vysokoškolském vzdělávání. Praha: Univerzita Karlova.

Vondrová, N., \& Žalská, J. (2012). Do student teachers attend to mathematics specific phenomena when observing mathematics teaching on video? Orbis scholae, 6(2), 85-101.

Vondrová, N., \& Žalská, J. (2015). Ability to notice mathematics specific phenomena: What exactly do student teachers attend to? Orbis Scholae, 9(2), 77-101.

Wiegerová, A., et al. (2015). Profesionalizace učitele mateřské školy z pohledu reformy kurikula. Zlín: Univerzita Tomáše bati ve Zlíně.

PhDr. Zora Syslová, Ph.D.,

Masarykova univerzita, Pedagogická fakulta, Katedra primárni pedagogiky;

e-mail: syslova@ped.muni.cz

SYSLOVÁ, Z. The Development of the Professional Vision of Students of Teaching for Nursery Schools

This study brings to academic discourse a view of the development of professional vision as one important dimension of the professionalism of nursery school teachers. The aim of the study is to describe the nature of the professional vision of students training for nursery school qualifications and the changes that occurred in it after systematic reflection on videos of actual education in nursery school. The respondents for the research project were 18 fermale students of Nursery School Teaching at the Education Faculty of Masaryk University. The data was gathered at the beginning of the term in which intensive work with video recording took place, and in the following term. The written commentaries of the students were analysed using two category systems. The first identified the orientation of their attention, and the second the mode of thinking about vision. The differences in orientation of their attention and the representation of intellectual operations between the two kinds of measurement were tested by a chi square test of independence. The results show that the attention of students is orientated above all to the teacher and that description predominates in their commentaries. After systematic work with analysis of the videos there were qualitative changes in the sub-process of thinking based on knowledge. Quantitative changes consisted in the length of commentaries, but also the number of categories represented in the subprocess of orientation of attention. The results show a positive advance in the professional vision of students and their way of thinking about educational reality.

Keywords: undergraduate education, professional vision, pre-school education, student, videos, orientation of attention. 